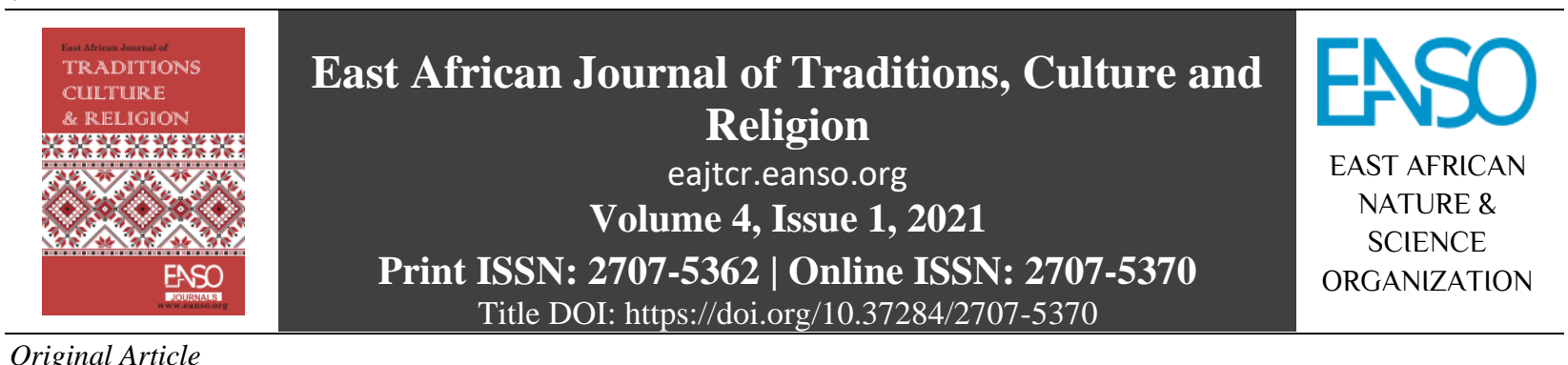

Original Article

\title{
Women and Church Ministry in Africa: Removing the Impasse Towards a Fruitful Theological Conversation.
}

\author{
Patrick Mwania, PhD \\ ${ }^{1}$ Tangaza University, P.O Box 15055-00509, Nairobi Kenya. \\ Author Correspondence Email: pmwania@yahoo.de.
}

Article DOI: https://doi.org/10.37284/eajtcr.4.1.465

\section{Date Published: ABSTRACT}

09 November 2021 Women in Africa, both in the traditional setup and in modern society form the cornerstone of the Church and society. They have spearheaded change

Keywords: in traditional and modern society and heralded the Gospel message on the African soil. Based on the formidable roles women played and the Women, influential areas of authority they occupied in the social, economic, Church Ministry, political, and religious dimensions of African traditional societies, such as Africa, priestesses, diviners, medicine women etc., I attempt to understand the

Theological Conversation, Catholic Church. role women play and the place they occupy in the Church and in society today taking the Catholic Church as a case study. The aim of this paper is to seek to understand the roles women play in society, as well as discerning how the roles could be promoted and improved for the betterment of the Church and society. For the discussion to achieve its objective, the following areas will be addressed: explore the place and the significance that traditional African society accorded to women; investigate the nature of women's involvement in the life of the community as well as the precise roles that traditional society assigned to women; discover the place of women in Christianity and some of the roles the Catholic Church assigns to women members as documented; understand some of the challenges women face as members of the Church and the roles they play in enhancing the Gospel; and finally attempt to provide some recommendations in response to some of the challenges identified.

\section{APA CITATION}

Mwania, P. (2021). Women and Church Ministry in Africa: Removing the Impasse Towards a Fruitful Theological Conversation. East African Journal of Traditions, Culture and Religion, 4(1), 80-90. https://doi.org/10.37284/eajtcr.4.1.465

\section{CHICAGO CITATION}

Mwania, Patrick. 2021. "Women and Church Ministry in Africa: Removing the Impasse Towards a Fruitful Theological Conversation.”. East African Journal of Traditions, Culture and Religion 4 (1), 80-90. https://doi.org/10.37284/eajtcr.4.1.465.

80 This work is licensed under a Creative Commons Attribution 4.0 International License. 


\section{HARVARD CITATION}

Mwania, P. (2021) "Women and Church Ministry in Africa: Removing the Impasse Towards a Fruitful Theological Conversation.", East African Journal of Traditions, Culture and Religion, 4(1), pp. 80-90. doi: 10.37284/eajtcr 4.1.465.

\section{IEEE CITATION}

P. Mwania, "Women and Church Ministry in Africa: Removing the Impasse Towards a Fruitful Theological Conversation.", EAJTCR, vol. 4, no. 1, pp. 80-90 Oct. 2021.

\section{MLA CITATION}

Mwania, Patrick. "Women and Church Ministry in Africa: Removing the Impasse Towards a Fruitful Theological Conversation." East African Journal of Traditions, Culture and Religion, Vol. 4, no. 1, Oct. 2021, pp. 80-90, doi:10.37284/eajtcr.4.1.465.

\section{INTRODUCTION}

Women in Africa - both in the traditional setup and in modern society - form the cornerstone of the Church and society; they have been and are still protagonists and key actors in the evolution, planning, development and growth of Christianity in Africa. They have spearheaded change in traditional and modern society and heralded the Gospel message on the African soil. Based on the formidable roles women played and the influential areas of authority they occupied in the social, economic, political, and religious dimensions of African traditional societies, such as priestesses, diviners, medicine women etc., I attempt to understand the role women play and the place they occupy in the Church and in society today taking the Catholic Church as a case study.

The aim of this paper is to seek to understand the roles women play in society, as well as discerning how the roles could be promoted and improved for the betterment of the Church and society. For the discussion to achieve its objective, the following areas will be addressed: explore the place and the significance that traditional African society accorded to women; investigate the nature of women's involvement in the life of the community as well as the precise roles that traditional society assigned to women; discover the place of women in Christianity and some of the roles the Catholic Church assigns to women members as documented; understand some of the challenges women face as members of the Church and the roles they play in enhancing the Gospel; and finally attempt to

\footnotetext{
1 John Mbiti, "Flowers in the Garden: The Role of Women in the African Traditional Religion," African Traditional Religions, 59.
}

provide some recommendations in response to some of the challenges identified.

\section{ANTHROPOLOGICAL AND SOCIOLOGICAL VIEWS OF WOMEN IN SOCIETY}

In my own Akamba cultural tradition and indeed in many other cultures in Africa, women were honoured and respected for their roles in society. According to writers such as; Ifi Amadiume, Males Daughters and Female Husbands; Musa Dube, The Post-Colonial Feminist Interpretation of the Bible and Mercy Amba Oduyoye, Daughters of Anowa; subordination of women as a practice is unknown in the African culture. These writers advance the opinion that social structures respected and held women highly because of the life sustaining powers inherent in women. Missionary teaching brought about a changed view. African traditional societies provide evidence that women have played irreplaceable roles in the socio-domestic, economic and political spheres of life. The place assumed by women in African cultural society confirms that they were significant pillars in traditional society, occupying important roles both in society and religion. Trying to figure out the importance of women in society and their centrality in the life of the family and clan, John Mbiti describes them as 'flowers in the garden who give beauty, scent, and seed to life' ${ }^{1}$ (p. 59). Anne Nasimiyu holds that women occupied important positions and were considered to be at the very heart and centre of the clan's life. ${ }^{2}$ Barra quotes a Lögbara proverb that says: 'a baby-girl means beautiful cows' and a

2 Anne Nasimiyu-Wasike, "Christology and an African Woman's Experience", Jesus in African Christianity: Experimentation and Diversity in African Christology, (2003):60.

81 This work is licensed under a Creative Commons Attribution 4.0 International License. 
Gikuyu proverb asserts that: 'the woman who has children does not desert her home and a barren wife never gives thanks.' 3 Women were often seen as sustainers and providers of the sustains family and the clan.

An African proverb says that not every woman can be a wife, and that the secret of the success or failure of any husband is his wife. Since marriage was a very important institution in Africa, responsible wifehood was a revered value in African society. Indeed, according to Mbiti marriage is the focus of existence among Africans. 'It is the point where all the members of a given community meet: the departed, the living and those yet to be born. ${ }^{4} \mathrm{~A}$ good wife was precious and a treasure not only to her husband but also to the extended family and the whole of society. Every husband was happy to marry a good woman, one from a good family and, in fact, the amount of bride price depended, in most cases, on these factors. Pride price is a sign of appreciation to the family of the bride. It was a token of gratitude and appreciation to the bride's parents for their efforts in bringing up their daughter. Moreover, it is significant because it shows on the one hand, the bridegroom's respect for his wife and in-laws, on the other, it is a pledge which obliges the husband to love and care for his wife.

Motherhood was a valued responsibility and a much sought-after role, and as such, the dream and means of self-fulfilment for every young woman. Because motherhood and womanhood in African traditional society is highly respected, women remain indispensable pillars and cornerstones of a wellfunctioning social set up. The African woman is the life-giving ability is seen in procreation, maintenance, and protection of the life of the clan in all its dimensions. However, her reproductive and motherly roles go beyond the biological dimension and encompass other aspects of life such as educating and instructing children on the way to

\footnotetext{
${ }^{3}$ Giuseppe Barra, 1000 Gikuyu Proverbs, (Nairobi: East African Literature Bureau, 1960), 60.

${ }^{4}$ John Mbiti, African Religion and Philosophy (Oxford: Heinemann, 1997), 130.

5 Aywald Shorter, African Christian Spirituality (London: Geoffrey Chapman, 1978), 152.

${ }^{6}$ Patrick Mwania, The African Woman as an Agent of Evangelization: Her Role and Function in the Missionary
}

live, and disseminating the virtues, values and norms of the society to the young ones ${ }^{5}$. As a consequence of her fertility and her knowledge of the secrets of life, a woman is considered to have an advantage over men. As a mother, a woman is the guardian of natural fertility in so far as she carries the potential of human life.

In the political sphere, it is important to emphasize that in many societies, and especially those which are matrilineal, power is based on 'seniority rather than on gender. ${ }^{6}$ In such communities, women were not confined to the household, as many authors, particularly western ones, have stated but rather they had important roles to play in the political arena, and indeed their roles were not subordinated to those of their male counterparts but rather complemented them. Loth maintains that in societies where power was not based on sexual inequality women such as Donna Veronica and Donna Susanne di Nobrera of the ancient Congo, had important leadership roles in their society as regents, co-regents, city founders, army officers, soldiers, bodyguards etc. ${ }^{7}$ Sudarkasa argues; except in the Islamic societies, African women were conspicuous in high places they occupied during the pre-colonial times; they held respected titles such as Queen Mother, Queen-Sister, Princess, Chief, as well as other significant offices in towns and villages. $^{8}$

Indeed, Africa of the late $19^{\text {th }}$ and early $20^{\text {th }}$ century and even today, knew a kind of political system which permitted women's representation in the governance and administration of society. Some societies, particularly those which were ruled by kings like the Akan and the Twi of Ghana, the Baganda of Uganda, the Shona of Zimbabwe, the Loango of Congo, some tribes in Ethiopia, Rwanda and Nigeria, had female political representatives in the person of the Queen, who were entrusted with special powers besides those of the king. Sometimes

Activity of the Church in Africa (Aachen: Shaker Verlag, 2009), 100.

${ }^{7}$ Heinrich Loth, Women in Ancient Africa, (Westport, Connectcut: L Hill\&Company), 31.

${ }^{8}$ Niara Sudarkasa, "The Status of Women in Indigenous African Societies" The Individual and the Community in the African Traditional Religion (Hamburg: Lit Verlag, 1998):73. 
these women had absolute power and autonomy over all their subjects and their word was authoritative and binding. In some cases, the Queen was considered divine because, besides military and economic responsibilities, she had strong cultic powers - sometimes as spirit mediums - power which won her great recognition.

In the economic sphere, women were assigned vital roles in production. Philomena Mwaura observes that both among the settled and the nomadic groups, women had vital roles in agriculture, manufacturing and trade which they carried out in order to provide material resources for the care of their families. ${ }^{9}$ Whether through the bride wealth given to their family by the husband's family or food production through cultivation and animal husbandry, women formed a basic unit of economic production. In some communities as pointed out quite comprehensively by authors like Ifi Amadiume and Mercy Amba Aduyoye, ${ }^{10}$ women had during the pre-colonial Africa vital roles in the economic wellbeing of their communities. In Kenya among the Kamba, Gikuyu and other Bantu speaking groups, women had a monopoly of the land. They were the major food producers and they did not only have access to land but determined its use. According to Routledge, the woman among the Gikuyu people was the homemaker on whom the paramount duty of food supply fell. ${ }^{11}$

Coming to the religious roles of women in Africa, Nasimiyu found their place at the centre of the clan and life of society as religious leaders, priests or medicine women and as arbitrators in marriage proposals as well. '... She [the woman] stands at the centre of the life of the clan. She is a multiple personality: a religious leader, for example, diviner, seer, medium, priestess, medicine person,

\footnotetext{
9 Philomena Mwaura, "Women in Kenya Between Tradition and Modernity" Inkulturation Zwischen Tradition und Moderne, Kontexte - Begriffe - Modelle (Freiburg: University Press, 2000): 79.

10 Cf. Ifi Amadiume, Male Daughters, Female Husbands: Gender and Sex in an African Society and Mercy Amba Aduyoye, Daughters of Anowa: African Women and Patriarchy.

${ }^{11}$ Scoresby Routledge and Catherine Routledge, With a Pre-historic People: The Agikuyu of British East Africa (London: Cass, 1968), 121.
}

rainmaker and counsellor.' ${ }^{12}$ Moreover, other women even qualified to be called ancestors and 'living dead'. It is clear that the indigenous way of life revolved religious practices, and that woman played active roles in various activities related to household cults, the veneration of ancestors, communication with God and the instruction of young girls. In my opinion, these assignments were not based exclusively on gender lines as some scholars have mistakenly tried to prove. Ekeya and Edet, have underlined that the cultic religious acts of worship in Africa were not exclusively the duty of men but also of women. ${ }^{13}$

In the African psychotherapy, women were diviners and acted as intermediaries between two worlds, the world of human beings and the world of the spirits and their work was to facilitate good communication between the two. They also assumed the roles of healers and herbalists which were very significant professions in Africa. To eradicate sickness, a select group of women, and of course men, were raised to the special rank of spiritual leadership as indigenous doctors, healers and herbalists whose function was to heal and to protect society from evil attacks and diseases.

\section{Anthropological and Sociological place of Women in the Church Today}

If one asked some of the Christians about the status of women in their respective churches today, many would certainly say that women are the backbone of the African Church. Women have been doing critical service in the Church and they have excelled in their leadership responsibilities whenever they have been given the chance. Thanks to Vatican Council II which was a decisive moment in the life of the Church, women who in the pre-Vatican II

\footnotetext{
${ }^{12}$ Anne Nasimiyu-Wasike, "Christology and an African Woman's Experience", 50.

${ }^{13}$ Cf. Rosemary EDET \& Bette Ekeya, "Church Women of Africa: A Theological Community," With Passion and Compassion; Third World Women Doing Theology Reflections from the Women's Commission of the Ecumenical Association of Third World Theologians (Maryknoll, NY: Orbis, 1988): 6.
} 
Church had not received enough recognition for their roles, came to be acknowledged and appreciated. After Vatican II, women moved from the margins to the centre. That is why women in the Catholic Church today have taken on roles that had previously been withheld from them such as: eucharistic ministers, lectors, catechists, leaders in different administrative groups such as Parish Pastoral Councils (PPC) and Small Christian Communities. Today Small Christian Communities would not be able to function without women. Women play a very significant role as Christian mothers responsible for introducing children to the faith.

Arguably, women issues such as their equality in value with men, their human dignity and their potential empowerment in the Church have become issues of great concern not only in Africa but all over the world. Indeed, the place of women's involvement in the Church's mission and ministry is of vital relevance especially at this time when the Church is being accused of being male-defined. The urgent call is for the Church is to assign to women their rightful place in both Church and society according to the model of Christ Himself whose mode of operation was inclusive and empowering.

The Bible can be a very important resource for the study of women's issues in the Church. The Old Testament is rich in texts that support positive regard for and appreciation of women in the Church. The Creation narratives in the book of Genesis make it very clear that male and female were created in the image and likeness of God and were together made responsible for making the earth fruitful (Gen 1: 27). In the Exodus-event, women worked concertedly with God in preserving the life of Israel as a nation and that of Moses as God's instrument of liberation for the nation (Ex 2:1-11). While Moses' own mother and his sister raised Moses for Pharaoh's daughter, Zipporah took him as her husband, provided him with a home thereby saving him from God's destroying anger on account of his failure to circumcise his son (Ex 2:15-22; 4:24-26). Other women whom God used as instruments for the realization of his salvific plan was Hagar, Rebecca, Rachel, Leah, Hannah, Manaoh's wife, and Ruth. Rebecca, for example, acted as an instrument of God's salvation. She helped Jacob acquire the paternal blessing from Isaac and thereby served as God's instrument at a decisive moment in Israel's history (Gen 27:1-29, 41-28:5).

Women could participate as worshipers and official religious leaders in Israel. They could take the socalled Nazarite vow (Num 6:1-8). Apart from priesthood, which was reserved to men alone, there were religious functions and offices open to women. One of these was the office of prophet. In the Old Testament women like Miriam, Deborah, Huldah, Noadiah and Isaiah's wife were called by God to the office of prophet and entrusted with the function of proclaiming his word to the people. The liberation struggle of the Israelites in Egypt had been initiated by God through the actions of five courageous women who dared to defy the Pharaoh: the Hebrew midwives, Shiphrah and Puah, the mother and sister of Moses, and the daughter of Pharaoh. Through their assistance, Moses fulfilled the mission entrusted to him by God.

The New Testament writings witness to various women who contributed greatly to the life and ministry of Jesus as well as to the growth and expansion of the early Church. Jesus' mother Mary is a vivid example of how women played a great role in the history of human salvation. By consenting to God's request to become the mother of the Saviour, Mary became a key person in God's messianic purpose. Together with Elizabeth, her cousin, she was the first to receive the news of the coming Messiah and the first to sing and prophesy concerning the role of Jesus (Lk 1: 26-56). The Prophetess Anna is also worth mentioning for her role of prophesying about Jesus at the Temple of Jerusalem as mentioned in the Gospel according to Luke. The synoptic Gospels give accounts of the women who accompanied Jesus during his ministry. After the Resurrection, the women became agents in communicating the Easter message and key players in building up the first Christian communities. Jesus embraced women with love, concern and empathy in a non-judgemental way like in the case of the widow, who had lost the only child or the woman at the well, the woman caught in adultery etc. He involved them in his mission and by so doing empowered them to move from the periphery of his work to being disciples and leaders. Jesus gave women their true worth and dignity by relating to them in an open and honest way and by considering them as active ministers of the Kingdom. 
A close look at the early moments of the history of Christianity in Africa shows that women, single, married and religious, formed, as they still do today, the heart of the Church communities. As Kalu states, 'women became protagonists and key actors in the evolution, development and growth of Christianity in Africa'. ${ }^{14}$ Remarkably, women in the early years of evangelization not only made up the majority in the Church but they were among those who were challenged by the Gospel and took responsibility to act. Women's roles have ranged from being committed recipients and authentic propagators of the Word and bold defenders of the faith. Some are [have been] being prominent founders and leaders of diverse African Independent, Charismatic and Neo-Pentecostal churches, bishops, pastors and evangelists, prophetesses, prayer leaders, healers, and charismatic preachers. Through these varied kinds of participation, women have contributed much to the growth of Christianity in Africa.

Elizabeth Isichei cites concrete cases of local women converts who experienced the new religion as good and convincing and who gave their best to propagate it to others in their families and in their neighbourhood. Women were among the first converts to Christianity and were the most ardent believers. ${ }^{15}$ Women were also the most committed and enthusiastic local evangelists who in many cases took charge of parishes and outstations and provided for their spiritual and material needs. The Christian message was a source of liberation because it advocated equal treatment of both sexes. Women, often uneducated, took charge of pastoral work in church communities; they bore witness to the life and demands of the Good News they had received and by so doing played a significant role in the evangelization of Africa. In most cases they witnessed to their faith and the Gospel values in their families and in other social groups, in Christian and non-Christian gatherings, in schools and centres of education as well as in health centres and in other areas of social significance.

${ }^{14}$ Cf Ogbu U. Kalu, African Christianity: An African Story (Trenton, NJ: African World Press, 2007), 360.

15 Cf. Elizabeth Isichei, A History of Christianity in Africa, Grand Rapids (Michigan: William B. Eerdmans Publishing Company, 1995), 190.
In his Post-Synodal Apostolic Exhortation 'Ecclesia in Africa', Pope St John Paul II acknowledged some of these women and their formidable accomplishments in the history of the evangelization of the African continent. The Pope mentioned some noble women like Saints Felicitas and Perpetua, Saints Monica and Thecla, who in the first centuries of the Church in Africa bore their own witness to Christ and the word of God, some to the point of dying for Christ as martyrs. In this way they played an indispensable role in the Church's essential duty of communicating the Gospel. By mentioning Blessed Clementina Anwarite from Congo, Victoria Rasoamanarivo from Madagascar, and Josephine Bakhita of Sudan the Pope acknowledged with great appreciation the growing number of saints of African origin. ${ }^{16}$ Countless African women and men through many generations have contributed enormously to the growth and expansion of Christianity in Africa by their heroic, selfless dedication and their exemplary lives of witnesses. To them, and to all her ancestors in faith, the African Church owes gratitude and honour as well as profound respect for their proverbial dedication, their efforts and contribution towards making the African Church what it is today.

\section{Varieties of Ministries for Women in the Church Today}

It is true that the number of women in the Church is bigger than that of men and this is not only true in the mainstream Churches but also in the new religious movements. One of the reasons given is that unlike western Christianity, which gave little attention to the inclusion of women in leadership, independent churches, especially those which are Pentecostal in character, teach that both men and women receive the same gifts of the Holy Spirit. The gifts endowed women with the ability to dream, see visions, prophesy, preach, teach, exorcise, heal, and take up leadership roles. In short, these movements provide women with chances to recover their traditional status and positions such as mediums, diviners, prophetesses, medicine persons,

16 John Paul II, Post Synodal Apostolic Exhortation Ecclesia in Africa, (Rome: Libreria Editrice Vaticana, 2012), n. 34.

85 | This work is licensed under a Creative Commons Attribution 4.0 International License. 
herbalists and priestesses, which the missionaries undermined. Unlike mainstream churches independent churches are inclusive and recognize women as full members, giving them a feeling of acceptance and a sense of belonging.

\section{Lay Women in Christian Associations}

In order to allow lay people to be more involved Church life, the Catholic Church came up with Catholic lay movements or associations for men and women. Among them are: Legio Mariae, Catholic Charismatic Renewal, Opus Dei and the 'Kenya National Council of Catholic Women'. Through such associations, African women have become principal players not only in the religious but also in the political sphere where women's presence and influence has been felt.

\section{Christian Women's Role as Mothers}

Pope John Paul once rightly observed that the family is the first and the vital cell of society because it is from the family that citizens come to birth, find the first school of the social virtues that are the animating principles of the existence and development of society itself. ${ }^{17}$ Women play significant roles in the family, their influence as Christian mothers is best expressed in the context of the family where they are wives and mothers. Their irreplaceable role in the Christian families and communities cannot therefore be underestimated. Women are aware that religious education and the upbringing of children are fundamental aspects of Christian family apostolate. As people with great influence in their families, the propagation of the Gospel in and outside families will to a great extent, though not exclusively, depend on them and their efforts.

\section{Women and the Small Christian Communities (SCCs)}

Another significant ecclesial reality in Eastern Africa is that of the Small Christian Communities described by the bishops of the African Synod as 'a new way of being Church' in Africa. These Small

17 John Paul II, Apostolic Exhortation Familiaris Consortio on the Role of Christian Family in the Modern World (Rome: Libreria Editrice Vaticana, 1982), n. 42.
Christian Communities have become groups in which women have been actively involved, and their presence and activity in pursuit of their Christian calling to evangelize have been greatly felt. According to Joe Healey in his book, Building the Church as Family of God: Evaluation of Small Christian Communities in Eastern Africa, women are in the majority in the Small Christian Communities and most of the leadership roles are in their hands. Women are the backbone of the Small Christian Communities and have used SCCs to deepen their faith. By praying together, reading the word of God and sharing it, and interpreting it in the light of their life situations and problems, women have been enabled to develop a close relationship among themselves and God. Like a Christian family, the members of a SCC discuss and help each other identify their problems, reflect on them, find solutions together and carry them out as a community. These communities have provided suitable opportunities for women to live their Christian faith in a more involved manner. They are good centres for evangelizing women and families; they provide opportunities for Christian formation and missionary outreach.

\section{Catholic Women's Associations (CWAs)}

The coming together of women in a body called 'Catholic Women's Association' has proved to be very instrumental for women's involvement in the life and mission of the Church. In these Associations, which exist in almost every diocese, women are enabled to participate and use their God given talents and gifts in building up God's Kingdom on earth. The Associations provide opportunities for women to bear living witness to the Gospel and to become the 'leaven in the dough' (Cf. Mt 13:33) in areas where their presence is felt, and especially in the struggle for women's empowerment, the promotion of human dignity and the search for justice and peace. Women organizations as ways and means of promoting women's involvement in the Church are a sign of the times, in fact, one of the contemporary religious experiences of women in Africa. According to Edet, 'the phenomenon of women coming together in

86 This work is licensed under a Creative Commons Attribution 4.0 International License. 
groups is designed to direct Church action toward renewal and service' and 'the discovery and sharing of professional competence of women in interfaith fashions' are two prevalent trends in Africa which 'assert a woman's right as a mature Christian and, as such, capable of functioning in any role of the Church. ${ }^{18}$

The primary aim and objective of Catholic Women's Associations is to unite the Catholic women's organizations in the area represented by each episcopal conference, and unify their purpose and direction in religious, educational, social, cultural and economic fields. As national bodies, they have first and foremost a coordinating and unifying function on behalf of the episcopal conference of each country. They also have a doctrinal function in the sense that they aim at the doctrinal and spiritual Christian formation of all the members of Catholic women's organisations by emphasising unity and deeper participation in the liturgy, thereby leading to a greater understanding of Christianity in today's world. A profound spiritual life and faith is of great significance for the Church and that is why spiritual formation, a life of contemplation and prayer, are important elements in the life of all Catholic women's organizations. Another objective of Catholic Women's Associations is social action. The members of these organizations are helped to become more conscious of their social responsibilities in the Church and in society. Through seminars and workshops, women are animated in their different roles and vocation as wives and mothers.

\section{The Role of Women among New Religious Movements}

One phenomenon in Africa that could be regarded as the fruit of the seed of Christianity in the subSaharan Africa, or a sign of maturity of faith is the emergence of new 'Christian Religious Movements'. These movements, commonly

18 Rosemary Edet, "Christianity and the African Woman", The Will to Arise (Maryknoll, NY: Orbis Books, 1992): 132.

19 Ogbu U. Kalu, Power, Poverty and Prayer: The Challenges of Poverty and Pluralism in African Christianity 1960-1996, (Frankfurt: Peter Lang, 2000), 105. referred to as AICs, have recognizable elements of the traditional religions with the influence of historic and modern churches as their main characteristic. These movements, which Kalu describes as 'increasingly creative in their pneumatic emphasis, in the use of the Bible, innovative gender ideology, African religion and culture' ${ }^{19}$ have been established as a reaction to missionary activities which were largely negative to African culture.

Women have played an important role in the founding of African churches. There are many AICs as well as Charismatic and Neo-Pentecostal churches founded by women. According to Barrett, hundreds out of seven thousand Christian movements owe their foundation to women. ${ }^{20}$ Women are also visible in these religious movements as founders, leaders, prophets, healers, evangelists etc. In most of them, women comprise the greatest number of adherents. Some of the reasons why women join these movements are: the wish to change their social order, alter conventionally accepted relationships between males and females, alleviate the physical, moral, and emotional suffering of women and finally, to enact these changes and the belief that these wishes will find fulfilment in these new religious movements.

\section{Challenges Facing Women Ministries Today}

Rose Uchem propagates a narrative that the Catholic Church and some other main stream Churches are male-oriented, leaving women little or no place in the decision-making process or in positions of authority. ${ }^{21}$ This belief has made some women become sceptical as to whether men, who of course benefit from and are favoured by the structurally male-defined Church, can handle women's issues with objectivity. Women question whether men can contribute objectively and in a positive way to the question of women's

\footnotetext{
${ }^{20}$ Cf. D. B. BARRET, Schism and Renewal in Africa: An Analysis of Six Thousand Religious Movements, p. 148.

${ }^{21}$ Cf. Rose Uchem, Beyond Veiling: A Response to the Issues in Women's Experience of Subjugation in African Christian Cultures (Enugu: SNAAP Press, 2002), 72.
} 
participation and their rightful place in the Church. Some women writers, among them Rose Uchem, ${ }^{22}$ Teresa Okure, Mercy Amba Oduyoye, have underlined the fact that women have been unjustly relegated to a secondary and inferior role within the male-dominated Church. According to them, women have fallen prey, whether in social or in ecclesial structures, to the traditional stereotype of inferiority based on male superiority and chauvinism. For them, the principle of patriarchy is responsible for women's oppression, as it considers women inferior to men and confines them to the bottom rung in the Church hierarchy and tradition. They believe that the ecclesiastical structures are pyramidal and authoritative in nature, leaving women marginalised and pushing them to the point of non-involvement. They feel that women are excluded from the Church's decision-making bodies and from the active mission of the Church and have been confined to the place of those who are, as the French theologian Yves Congar once put it, destined to 'pray, pay and obey'. While this may be true, it might appear exaggerated.

There are some factors that have affected the way women's roles in the Church are conceived. Some observers reckon that the place of women in the church has been influenced by three factors: the biblical culture from which Christianity originated, the improper interpretation of some verses of the Bible, and modern African culture. Some Church Fathers in their Christian anthropology presented women in a very negative light. ${ }^{23}$ They saw women as people possessing God's image in a merely secondary way. Women according to these fathers were prone to sin and, for that reason, only good for procreative, subordinate roles as wives and mothers. They equated what they called the 'ratio superior', the higher part which devotes itself to the contemplation of eternal truths, with man, and the 'ratio inferior', which caters for temporal needs, with woman. This automatically presented man as superior and theomorphic and woman subordinate and not theomorphic. The reader who is interested

\footnotetext{
${ }^{22}$ Among the popular books where the Nigerian religious Sisters argues against the subordination of women both in the society and in the Church is Overcoming Women Subordination: An Igbo African Christian Perspective: Envisioning an Inclusive Theology with Reference to Women written in 2002.
}

in reading further may refer to the book by Benardett Mbuy Beya entitled Women who are you?

One factor is the patriarchal stance of early Christian culture. Early Christian thought on sexual equality and the male-female relationship, was influenced and shaped by the androcentric Judaic, Greco-Roman traditions. According to these traditions, women are seen as inferior and subordinate while men are superior. According to these traditions, the 'male' is seen as the perfect sex, the only one created fully in God's image, the 'female' is just a 'helpmate' who can only achieve her perfection and reflect the real image of God when she has been married and joined to her husband. Accordingly, a woman was regarded as biologically, mentally, morally, and physically defective and, therefore, needed first to be transformed into a man to be saved. Women, by virtue of their sexual identity, empirically evident in the biological, psychological, and sociological realities of life, are seen as sharing less in the image of God and their subordination to men is therefore justified and in accordance with the plan of God. Critics and writers with a feminist orientation like Rose Uchem have used this argument to explain why the Catholic Church is a masculine church with only men in official church ministries.

Another factor is the negative interpretation of the biblical creation accounts and other scriptural texts in favour of the male gender. The two creation accounts in the book of Genesis and some verses in the Pauline letters have been misinterpreted to promote women's subordination and to downplay women's humanity. Traditionalists have argued that women, by virtue of being created second and from man's rib, are by nature inferior to, weaker than and subordinate to men. For centuries, the Yahwistic account of creation taught that man was ontologically superior, woman inferior; and that this was willed and ordered by God for the betterment of both men and women. Genesis 3:16, for instance, has been interpreted as implying a necessary

${ }^{23}$ The anthropology of some Church Fathers like St. Augustine, St. Thomas of Aquinas as well as protestant theologians like Martin Luther and Karl Barth are well known for their stereotyped attitude towards women as they consider them from creation inferior to men and so destined perpetually to male domination and influence. 
subjection of a woman to her husband as well as implying the husband's right to discipline his wife. All these texts have been used to prove that woman was responsible for the fall of man; she was considered a natural liar and the devil's agent. Of course, such an interpretation of the Bible is erroneous and therefore distorts the scope and intention of the Bible and also the original plan of God.

The Pauline Letters have also been misinterpreted to justify women's subordination. The first Letter to Timothy has been used to prove that the divine nature of man's ontological headship and women's subordination is crucial to all male-female role relationships. In addition, the first Letter to the Corinthians (1Cor 11: 3-16) and the Letter to the Ephesians (Eph 5: 21-33) argue for women's silence and their non-involvement in the Church. They are taken as proof that according to the divine order, the husband is the head of the wife and the submission of the woman is normative and irrevocable. To interpret them in this way is to misinterpret the concept of male headship and to wrongly infer man's superiority and his dominion over his wife. If there is any male 'headship', it should reflect the husband's duty and responsibility to care for his wife, to liberate her from any form of enslavement and unnecessary control.

Some of the African cultural practices seem to demean women. Notwithstanding the roles women played and the significant areas of authority they occupied in the social, economic, political, and religious dimensions of the traditional African society. One cause of female oppression that has been cited is male dominance regarding 'institutionalized sexually-linked practices and beliefs. Women have experienced violence, deprivation, wife beating, denial of their rights to possessions and inheritance, female genital mutilation, rape and other forms of sexual violence. African traditional worldview is predominantly except in cases of matrilineal societies - patriarchal and male-oriented, something that leads to the marginalization of women and relegated them to second place in society and later in the Church. In

\footnotetext{
${ }^{24}$ Uchem, Beyond Unveiling, 17-18.

${ }^{25} \mathrm{Cf}$. Uchem, Overcoming Women's Subjugation: An Igbo African and Christian Perspectives: Envisioning an
}

the traditional African context, society was generally patriarchal with the male gender being dominant and the more preferred, thus leading to female submission and inferiority. It was not uncommon for such a cultural mentality to lead to systematic violence against women. It also led to women being looked upon as perpetually dependent beings who always had to be directed and protected by men.

In some communities such the Kamba people of Eastern Kenya, the Igbo of Eastern Nigeria, the Chagga of Tanzania, the Agikuyu of Kenya, to mention just a few, more value and importance was attached to a male child than to a female child. The strength of a woman was seen in her giving birth to a male child, something which gave her a great deal of pride and a place in her husband's home. ${ }^{24}$ The practice of polygamy in the African tradition was a practice that favoured men over women. Men were licensed to marry as many wives as they wished. In some communities, men measured their wealth and influence by the numbers of women they controlled. It was and is regarded as taboo, however, for a woman to have more than one husband. In the event of the husband's death, the woman was subjected to several gory and excruciating traditional funeral rites popularly known as 'widowhood'. In some cultures, the widow was made to sleep with the husband's corpse for a night, or drink the water used in washing the corpse if she was suspected of causing his death. In some traditions, the eldest man in the family inherited the woman, or she was evicted from the husband's house with her children, and her property confiscated. Though this was a positive thing aimed at giving custody and protection to the widow and orphans who would otherwise be exposed to dangers such as lack of basic resources for the widow etc, it was negative whenever widows have to be forced to be inherited.

According to Rose Uchem, Igbo women are politically, economically, psycho-socially, culturally, and religious/spiritually 'marginalized', 'subjugated', and 'discriminated against'. ${ }^{25}$ She argues that women's subjugation in Nigeria goes back many centuries She argues that the Islamic

Inclusive Theology with Reference to Women (Parkland, Florida: Dissertation Com., 2001), 170.

89 | This work is licensed under a Creative Commons Attribution 4.0 International License. 
Pioneers also contributed to the low status of women in Nigerian society. They regarded women as inferior human beings at the margins of society. Uchem goes further to extend the blame to the Nigerian male elite ruling class, who welcomed, supported and unquestionably helped in implementing these foreign policies. ${ }^{26}$

\section{Towards a Conversation on Holistic and Positive Christian Anthropology}

There is no doubt that in Christian faith and revelation, gender and sexuality are valuable gifts given by God to humanity and for a good purpose. Humankind, male and female, are created in the image and likeness of God. ${ }^{27}$ According to the original design of God, woman is equal to man and this equality is restored in Christ. Man and woman are principally equal but functionally different; equal in so far as they are both created in the image and likeness of God and that both have been cleansed from sin by Christ. They are functionally different in that they are created male and female with different talents and capabilities so that they can perform to complementary roles while living harmoniously together in the world. There should be no rivalry between men and women because of their differences in gender and role. Men and women should complement each other both in the Church and in the society. Their differences call for admiration and respect in a reciprocal self-giving and not result in a slave/master relationship. For the African Church to be authentically enculturated and fully evangelized, it must address cultural issues which violate fundamental gender and social justice issues. The subordination and subjugation of women in African cultural and ecclesial spheres, for instance, are cultural attitudes that are oppressive, and they are obstacles to the true liberation of men and women.

\section{CONCLUSION}

This discussion has been an attempt to explore the place and role of women in the African traditional societies and in the Church with the view of establishing a link, indeed a point of convergence between the Gospel and culture, Christianity and African traditional culture. The aim is to contribute

\footnotetext{
${ }^{26}$ Ibid., 46.
}

to the body of knowledge concerning the ongoing discussion of the way Christian faith and the Gospel can best dialogue with the African cultural context. It is an imperative that the Gospel should take root in African culture; it should incarnate itself in the people so that Africans who have embraced Christianity are able to identify themselves fully with the Gospel and Christian life. The nature of the Gospel demands that African Christians become authentic Christians and authentic Africans. One way of ensuring this is to consider women as active players in the life of the Church. This is in line with being truly African and Christian at the same time.

Indeed, Catholic women are known for their excellent contribution to the life of the Church and society. In the domestic church women are the first and indispensable preachers of the Word of God, which is the principal constitutive task of the mission of the Church. Starting from the family, where they are protagonists in the transmission and protection of life, women are the main instruments of evangelization. Their missionary tasks over and beyond their care of their own family include: catechising both catechumens and Christians, visiting other families, the poor, the sick and outcasts, involvement in retreats and sessions on spirituality, teaching religion in schools, working with the mass media and social communications, and the education and formation of children. However, their area of involvement depends on their availability and expertise and varies from parish to parish, diocese to diocese, and from country to country. Generally, women's activities can be categorised into four main areas: those of a pastoral nature, those of a spiritual nature, those of a developmental-economic nature and finally those of a social nature.

\section{This work is licensed under a Creative Commons Attribution 4.0 International License.}

